\title{
Transport and Behavior of Trace Metals in the Tsengwen River and Estuary
}

\author{
JIA-JANG HUNG \\ Institute of Marine Sciences \\ National Sun Yat-Sen University, Kaohsiung, Taiwan, R.O.C.
}

(Received 17 July 1990; revised 29 September 1990)

\begin{abstract}
Studies on the transport mechanisms and behaviors of six trace metals ( $F e, M n, C d, C u, P b$ and $Z n$ ) in the Tsengwen river and estuary were performed for the high-flow and low-flow seasons. Dissolved metals in the Tsengwen river are slightly higher than those in the pristine rivers but much lower than those in the heavily polluted rivers of the world. The riverborne dissolved $F e, M n, C u, P b$ and $Z n$ exhibited significant removals in the early estuarine transport; for $C d$, however, this was likely controlled by the mixing process in the estuary. Particulate and sediment metals, similar to dissolved metals, showed elevated concentrations in the middle river, but there was little difference throughout estuarine locations. The enriched levels of particulate and sediment metals with reference to backgrounds (shale's metals) were found in a sequence of $P b, C d>Z n, C u>F e, M n$.

Trace metals were principally transported by suspended particulates, accounting for over $93 \%$ of the total gross fluxes. Particulate $F e$ and $P b$ are mostly concentrated in the $F e-M n$ hydroxides and crystalline fractions. Particulate $M n, C u, Z n$ and $C d$ distribute rather significantly, in addition to $F e-M n$ hydroxides and crystalline fractions, in exchangeable and carbonate phases, carbonate and organic phases, carbonate phase, and exchangeable phase, respectively. The particulate speciation shows little difference between riverwater and estuarine water. The net fluxes of metals out of the estuary are modeled to be approximately $56 \%, 76 \%, 114 \%, 67 \%, 84 \%$ and $73 \%$ of dissolved influxes as well as $35 \%, 32 \%, 28 \%, 29 \%, 39 \%$ and $50 \%$ of particulate influxes, respectively for $\mathrm{Fe}, \mathrm{Mn}, \mathrm{Cd}, \mathrm{Cu}, \mathrm{Pb}$ and $\mathrm{Zn}$. The imbalance of metals between the dissolved and particulate phases is thought to result from metal deposition in the estuary.
\end{abstract}

\section{INTRODUCTION}

The riverine fluxes of trace metals to the oceans may depend greatly upon reactions that occur in estuaries ( $\mathrm{Li}$ et al., 1984; Byrd and Andreae, 1986). A 
large modification was usually found when the riverine metals passed through an estuary with great salinity gradients. Despite decades' of efforts towards understanding the behaviors of trace metals in the land-sea boundary, there continues to be considerable uncertainty about the estuarine processes involved in controlling the fate of riverborne metals (Sholkovitz, 1978; Windom et al., 1983; Keeney-Kennicutt and Presley, 1986; Byrd and Andreae, 1986; Waslenchuck and Windom, 1987). The study on the transport mechanisms of riverine trace metals is therefore necessary in understanding the biogeochemical cycles of metals in a regional land-sea system.

Numerous studies concerning the transport and flux of elements from the rivers of the world have been reported (Gibbs, 1973, 1977; Eaton, 1979; Yeats and Bewers, 1982; Stallard and Edmond, 1983; Maest, 1984; Byrd and Andreae, 1986; Keeney-Kennicutt and Presley, 1986). Martin and Meybeck (1979) have also compiled the data of elemental transport for twenty-two major rivers in the world. The estimated global flux of metals into the oceans, however, has been rather uncertain due to the lack of data in many countries. It has been evident that data supplied from areas in Asia would be especially valuable.

In order to understand the transport and behavior of the riverine trace metals, it is usually necessary to determine the distributions of trace metals in the dissolved, suspended and sedimented matters in a river system. The growing data show that the fluxed metals are mainly transported by the suspended matter, and the fate and toxic effects of the fluxes are highly dependent on specific forms rather than total inputs (Calmano and Forstner, 1983; Forstner and Wittmann, 1979; Salomons and Forstner, 1984). Therefore, the determination of trace metal speciation in the suspended particulate matter is important for understanding the environmental significance and biogeochemical cycles of metals.

Very few reliable data are available for a systematic description of metal geochemistry in the rivers and estuarys in Taiwan. We are concerned here with behavior of trace metals in the Tsengwen river system not only because the riverwater is essential to the agriculture of the river basin, but also as the estuary is an important area with regard to maricultures and fisheries. The aims of this study are to decribe the transport modes, distributions and behaviors of metals in the Tsengwen riverine system.

\section{MATERIALS AND METHODS}

\section{a. Sampling and pre-treatment}

Samples of water and sediment in the Tsengwen river and estuary were collected in September, 1986, and January, 1987, which represent the periods of 


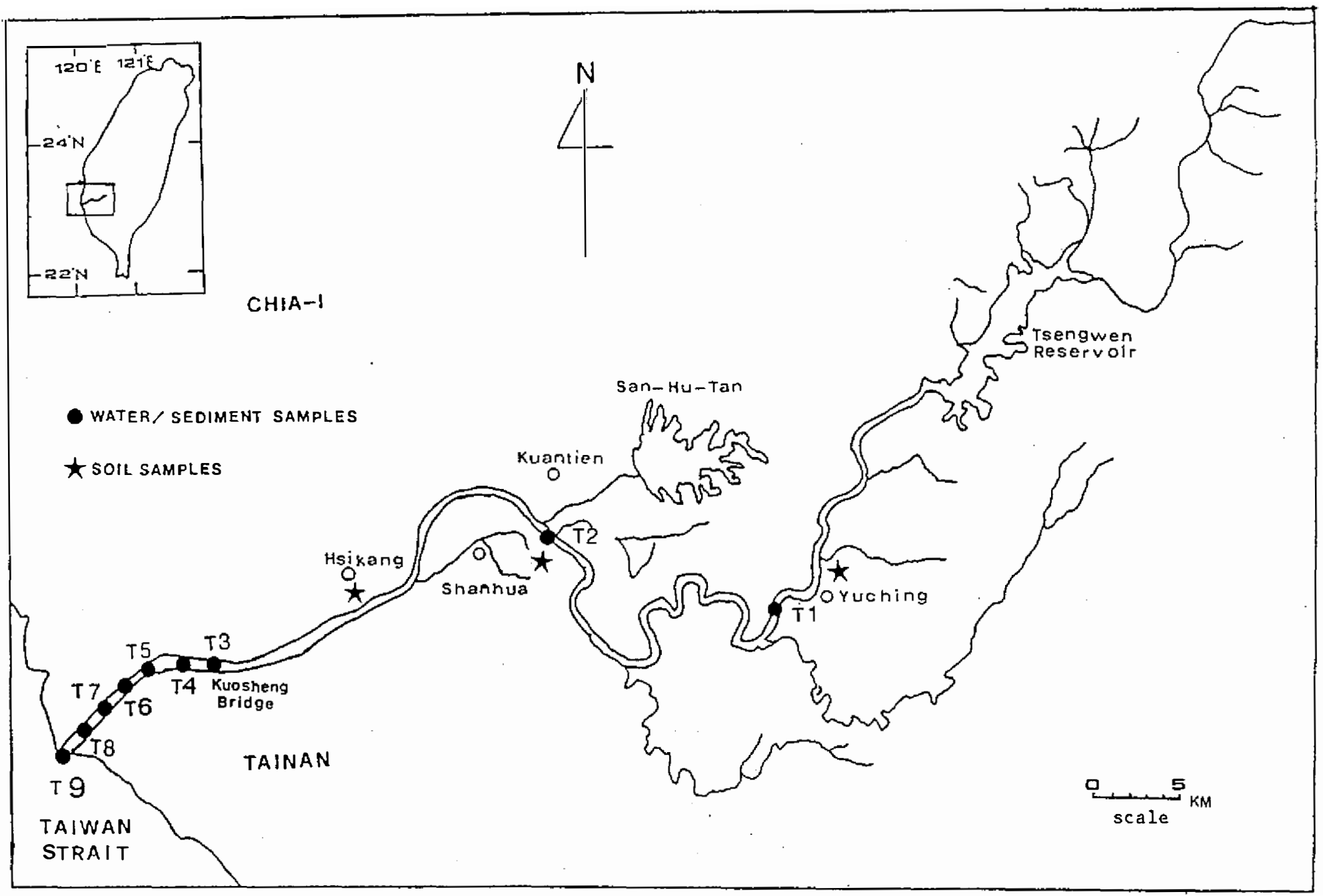


high-flow and low-flow, respectively. The sampling locations are shown in Fig. 1. A large volume of water $(60 \mathrm{~L})$ for each sample was taken, $25 \mathrm{~cm}$ below the surface by a horizontal water sampler (Ekman Birge) from the highway bridges over the river part and from aboard fishing boats in the estuary. Salinity was measured in situ with a salinometer (Hydro-Bios) and then precisely determined in the laboratory from solution density; the density was measured with a densitometer (Parr DMA 602). Sediments were taken with an Ekman Birge dredge. Soil samples were taken from the surface horizon of the drainage basin. Sediment and soil samples were air-dried, ground, and pestled to pass through a $1 \mathrm{~mm}$ nylon sieve, and then stored in plastic bottles.

We made two other cruises on June, 1987, (high-flow) and December, 1987, (low-flow) to take small volume $(2 \mathrm{~L})$ samples only for the analyses of dissolved metals. The sampling stations in the estuary, however, were physically much denser than those indicated in Fig. 1, by which the behaviors of dissolved metals in the estuary were expected to show up more clearly. An intensive survey of profile salinity in the estuary was also performed during the inter-tidal period of the last cruise, and the results are shown in Fig. 2.

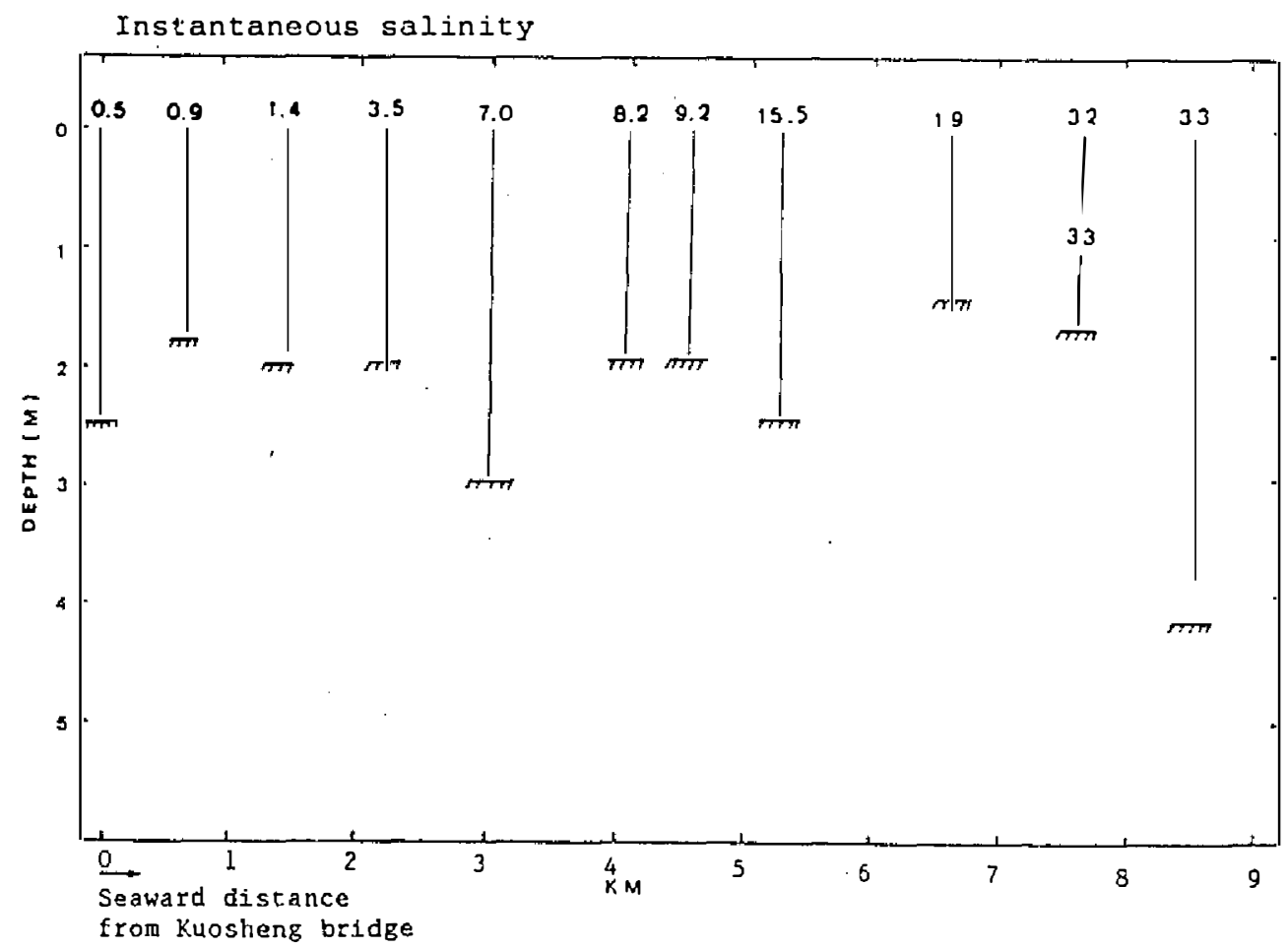

Fig. 2. Salinity profile of the Tsengwen estuary.

Two liters of each water sample were filtered through a $0.45 \mu \mathrm{m}$ Nalgene membrane filter which was pre-washed with acid. The filtered water was acid- 
ified to $\mathrm{pH}$ 1-2 and stored at $4^{\circ} \mathrm{C}$ for further analyses of dissolved metals. The remaining water of each sample from the first two cruises was ultracentrifuged at 12,000 rpm (Hitachi, model SCR $20 \mathrm{~B}$ ) to recover suspended matter, which was then dried in an oven at $105^{\circ} \mathrm{C}$ until a constant weight was reached. The dried samples were stored in a desiccator.

A portion of dried sediments and suspended particulates were resuspended in distilled-deionized water (DDW) to separate the clay fraction $(<2 \mu \mathrm{m})$ from other fractions by ultracentrifugation according to the Stokes' sedimentational principle (Osipow, 1977). The recovered clays from the sediments were dried again in an oven at $105^{\circ} \mathrm{C}$ and stored in a desiccator.

\section{b. Methods of analyses}

\section{Reagents and apparatus}

All reagents used in the experiments were analytical grade (Merck) and purified with Chelex-100 resin (Biorad, 200-400 mesh) whenever possible. Acids were subboiled $\left(\mathrm{HNO}_{3}, \mathrm{H}_{2} \mathrm{SO}_{4}\right)$ or superpure $\left(\mathrm{HClO}_{4}, \mathrm{HF}\right.$, Merck). All plasticware used in the analyses was cleaned by soaking in $10 \% \mathrm{HCl}$ and rinsed thoroughly with DDW. Standard solutions for atomic absorption spectrophotometry were prepared by dilution of Merck Titrisol standard solution with 0.2 $\%$ subboiled $\mathrm{HNO}_{3}$.

Teflon lined acid digestion bombs (Parr Instrument Co.) were used to decompose soils, sediments, and suspended particulates for total metal determinations, whereas the polycarbonate centrifuge tubes (Nalgene, $50 \mathrm{ml}$ ) were used for sequential extraction. The Perkin-Elmer 2380 atomic absorption spectrophotometer (AA) with a $D_{2}$ background corrector and equipped with an HGA 400 graphite furnace (GFAA) was used for trace metal determinations.

\section{Analytical procedures}

Dissolved trace metals $(F e, C d, C u, P b$ and $Z n$ ) were analyzed using the chelation back extraction method modified from Danielsson et al., (1982) and Statham (1985). Metals in a $500 \mathrm{ml}$ aliquot of riverine/estuarine water were preconcentrated by chelation with ammonium pyrrolidinedithiocarbonate (APDC) and diethylamonium diethyldithiocarbamate (DDDC) followed by freon ( 1,1 , 2-trichloro-1, 2, 2-trifluorethane) extraction, and the metals were then backextracted into a final $10 \mathrm{ml}$ dilute nitric acid solution. Manganese, however, was preconcentrated by the C18 SEP-PAK Catridge (Water Associates; Milford, USA). In most cases concentrated $Z n$ was high enough to be determined by flame-AA, whereas other metals were determined by GFAA. Riverine and coastal seawater reference materials (SLRS-1/CASS-1, National Research 
Table 1. Accuracy and precision of trace metal analyses in river and sea waters

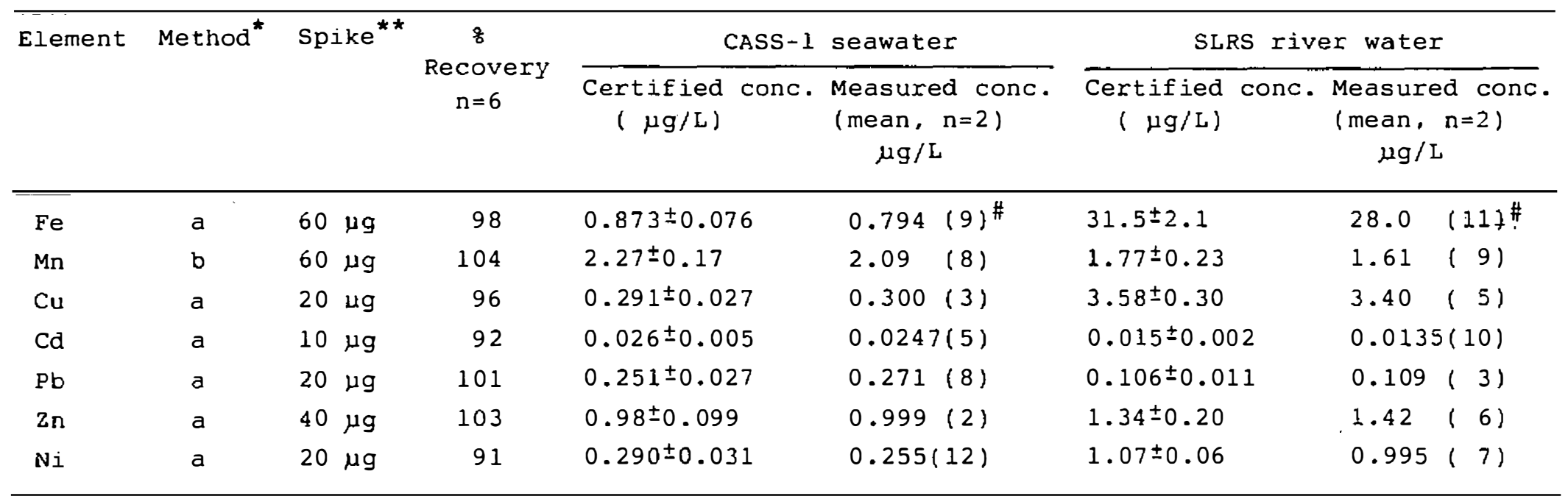

* a: APDC/DDDC-freon preconcentration - GFAA determination b: SEP-PAK C18 preconcentration - GFAA determination

** Metals were spiked in the coastal seawater off southwestern Taiwan

\# Values in parentheses are 8 deviations of measured conc. from certified conc. 
Council of Canada) were analyzed with the same procedures. The precision and accuracy of the analyses are better than $89 \%$ and $91 \%$, respectively for the river and the sea waters (Table 1 ).

Trace metals in soils, suspended and bottom sediments including their clay fractions, were determined by decomposing materials with an acid mixture ( $\mathrm{HNO}_{3}, \mathrm{HClO}_{4}$ and $\mathrm{HF}$ ) in Teflon lined acid digestion bombs, followed by the flame AA/GFAA measurement. Trace metal species in the suspended particulates were determined by a method of selective extraction/GFAA determination. Fractions of exchangeable, carbonate, $F e-M n$ oxides, organic and crystalline forms were separated and determined. Detailed procedures for determining the total number and species of particulate metals has been decribed elsewhere (Hung, 1988).

\section{RESULTS AND DISCUSSION}

The Tsengwen river is one of the major river in Taiwan. It has a length of $138.5 \mathrm{~km}$ and a drainage area of $1176.6 \mathrm{~km}^{2}$. The river originates from the Wanshui mountain of the Central Range, flowing through the Chai-I and Tainan counties, toward southwest to reach sea in the Chiku area.

The average annual discharge of the river for the period of 1972-1981 was $1.40 \times 10^{9} \mathrm{~m}^{3} \mathrm{yr}^{-1}$ for water and $1.43 \times 10^{6}$ ton $\mathrm{yr}^{-1}$ for solid (hydrological yearbook of Taiwan, R.O.C.). The flow rate is slightly reduced by the Tsengwen resvoir in the upper basin, but in general it is higher in the wet season (MayOctober) than in the dry season (November-April). The middle and down stream portions of the river have been polluted by either domestic or industrial wastewater, and the situation is getting worse, especially during the dry season.

\section{a. Dissolved metals in the river and the estuary}

Dissolved metals in the Tsengwen river and estuary are displayed in Fig. 3. The concentrations of metals was plotted as a function of salinity in the estuary and as a function of the landward distance with reference to the salt intrusion point in the river portion. Data for the river were obtained from the averaged concentrations of two cruises in 1986 and 1987, respectively, for the high-flow and low-flow, whereas data for the estuary were the results of cruises in June (high-flow) and December (low-flow), 1987. Estuary data from the cruises in September, 1986, and January, 1987, were not presented and discussed because of inadequate data, particularly in the low salinity range (0-9\%) where we did not collect any samples. Meanwhile, the salinity of a sampling location in the estuary was not the same for any two cruises, therefore the data obtained from the similar flow conditions but different cruises were not suitable to be 


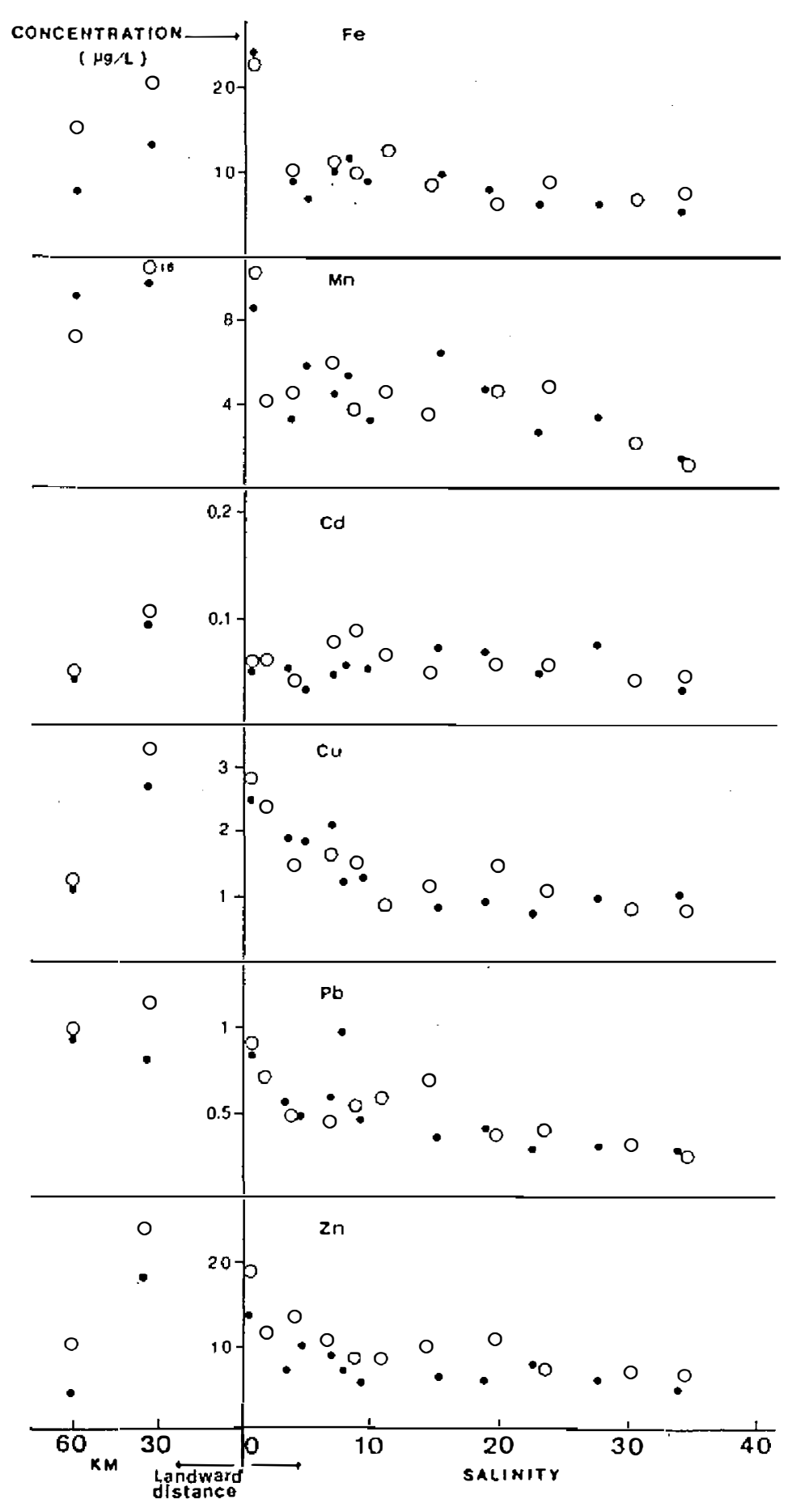

Fig. 3. Concentrations of dissolved metals in the Tsengwen river and estuary; $(\cdot)$ is during high flow; $(0)$ is during low flow. 
Table 2. Concentrations of dissolved metals in riverwaters, $\mu g / L$

\begin{tabular}{|c|c|c|c|c|c|c|}
\hline River & $\mathrm{Fe}$ & $M n$ & $\mathrm{Cd}$ & $\mathrm{Cu}$ & $\mathrm{Pb}$ & $2 n$ \\
\hline $\begin{array}{l}\text { Tsengwen } \\
\text { (this stud }\end{array}$ & $\begin{array}{l}8.2-23.3 \\
\text { (dy) }\end{array}$ & $3.1-16$ & $0.04-0.11$ & $1.09-3.3$ & $0.82-1.14$ & $4.4-24.4$ \\
\hline Kaoping $^{a}$ & $7-24$ & $1.3-4.8$ & $0.03-0.055$ & $1.02-2.3$ & $0.32-0.5$ & $6.4-16.2$ \\
\hline Background & 55 & 6 & 0.02 & 1 & 0.2 & 10 \\
\hline Mississippi & i C & io & 0.1 & 2 & 0.2 & 10 \\
\hline St. Lawreno & ce d 55 & 6.3 & 0.11 & 2.5 & - & 8.6 \\
\hline Amazon $\mathrm{e}$ & 34 & 19 & - & 1.77 & - & - \\
\hline Yukon e & 50 & 20 & - & 2.0 & - & - \\
\hline Raxitan $f$ & $25.8-76.5$ & $4.7-34.7$ & $0.4-0.9$ & $2.4-4.1$ & $0.5-1.9$ & $30.1-109$ \\
\hline Rhine $\mathrm{g}$ & 35 & 5.2 & 5.5 & 34 & $5 \%$ & 330 \\
\hline
\end{tabular}

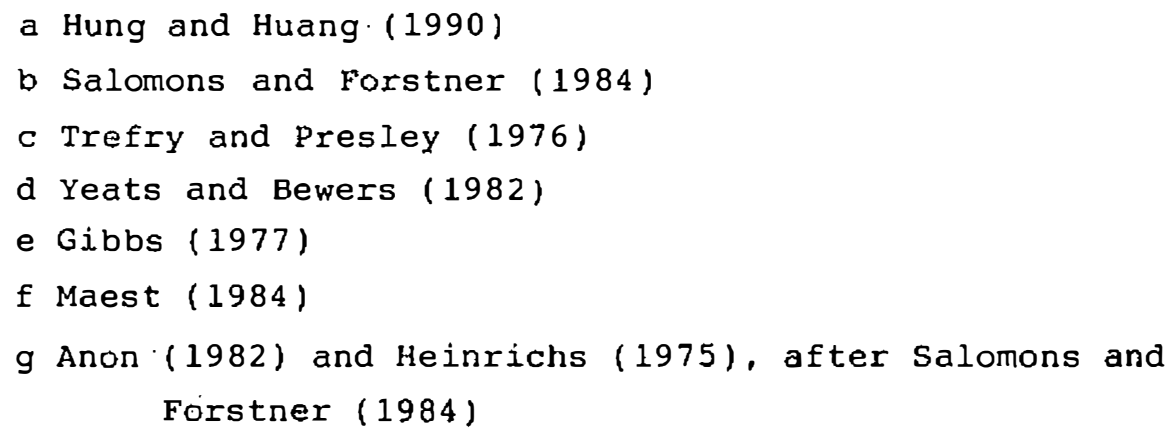

combined for this discussion.

From Fig. 3 we found that all metals generally have higher concentrations in the middle and down streams than in the upper stream of the river. This is ascribed to the fact that the middle and lower sections of the river have been contaminated with metals. Compared to other rivers in the world, concentrations of metals in the Tsengwen riverwater are somewhat higher than those in the rivers without pollution (backgrounds), but they are much lower than those in the severely polluted river (Rhine) (Table 2). As the Tsengwen riverwater mixed with seawater in the estuary, dissolved river-borne metals with the exception of cadmium behaved non-conservatively, removals of metals from a solution over the low salinity range (0-10\%) were found. Cadmium, however, did not display a significant removal or addition throughout the estuary. These geochemical reactions were judged from the comparison of concentrations of 
metals that were positive or negative deviations from mixing lines between the riverine and oceanic end members.

The geochemical processes involved in non-conservative removals are complicated. Nevertheless, several publications reported that flocculation as well as adsorption and coprecipitation could be reponsible for removals of geochemically reactive metals, while complexation with chloride or desorption from particulates may cause an increase of $C d$ in the estuary (Sholkovitz, 1978; Galloway,1979; Eaton, 1979; Klinkhammer and Bender, 1981; Li et al., 1984; Waslenchuck and Windom, 1987). Overall for dissolved metals, the concentration was higher in the dry seasons than in the wet seasons in the river but there was no significant difference in the estuary. Apparently the distributions of dissolved metals in both river and estuary were dominated by the processes of pollutant inputs, estuarine physical-chemical reactions, and flow conditions, presuming that biological effects can be neglected.

\section{b. Metals in sediments}

Metal distributions in the suspended particulates and bottom sediments are shown in Fig. 4. Metal concentrations are expressed in terms of total sediment/particulate and clay fractions of sediment/particulate. Metals in the clay fractions of the sediments are higher than those in the total sediments because metals are usually concentrated in small particles. However, metal distributions have similar trends for both total and clay fractions of sediments in the Tsengwen river and estuary. In general, metals are little different in the Tsengwen river and estuary except for $C d$ in the middle river where it could have been polluted by the $C d$ associated phosphorus fertilizers. Overall, metals in the Tsengwen estuary are comparable to those in the relatively unpolluted $S t$. Lawrence estuary (Loring, 1978; $C u$ : $24-25 \mathrm{ppm}, Z n$ : $84-115 \mathrm{ppm}, P b$ : 21-30 ppm, $C d: 0.22-0.26 \mathrm{ppm}$ ), but they are much lower than those in the polluted Rhine-Meuse estuary (Salomons and Mook, 1977; Cu: $99 \mathrm{ppm}, Z n: 870 \mathrm{ppm}$, $P b: 213 \mathrm{ppm}, C d: 5 \mathrm{ppm})$. Variations of $F e$ and $M n$ distributions were probably due to their lithological characteristics. Forstner and Wittmann (1979) have found that in the less contaminated material a general decrease of metal concentration is found with increasing particle diameter, whereas in the polluted material there is a typical increase of metal concentrations in the clay and silt fractions. Therefore, it is usually necessary to compare metal distribution on the basis of a standard with regard to particle size.

Metal distributions in total and clay fractions of suspended particulates also showed a similar trend, this is due to the fact that suspended particulates contain mainly fine particles, predominantly in silt, clay minerals and organic materials. As a result, metal concentrations in the suspended particulates were 


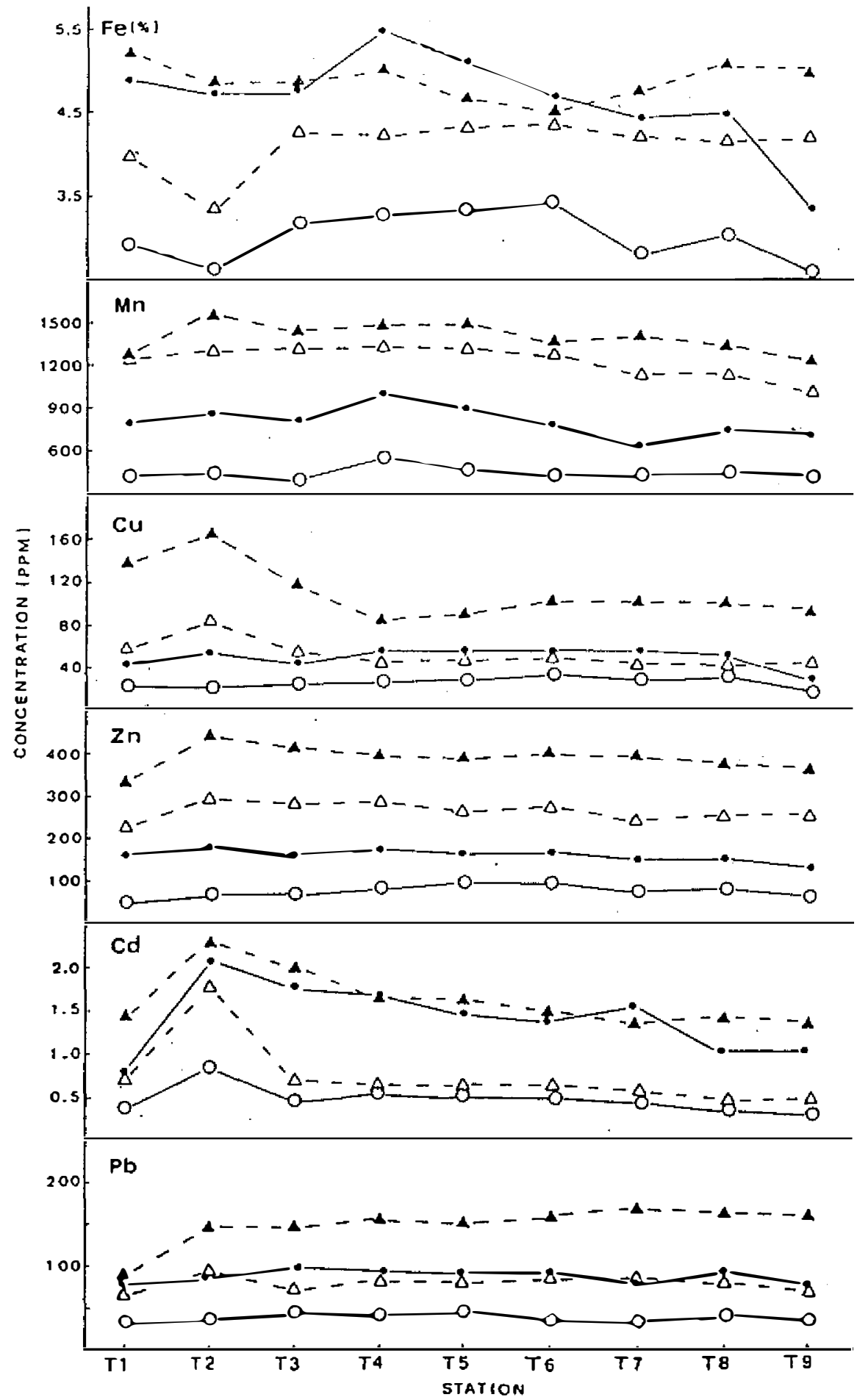

Fig. 4. Concentrations of metals in suspended particulates and bottom sediments of the Tsengwen river and estuary; $(0)$ is the average conc. of total sediments; ( $\bullet$ ) is conc. in $<2 \mu \mathrm{m}$ sediments; $(\Delta)$ is the average conc. of total suspended particulates; $(\Lambda)$ is the conc. in $<2 \mu m$ suspended particulates. 
Table 3. Geoaccumulation indices for metals in the bottom sediments and suspended particulates from the Tsengwen river and estuary.

\begin{tabular}{|c|c|c|c|c|c|c|c|c|c|}
\hline \multirow[t]{2}{*}{$I_{\text {geo }}$} & \multirow{2}{*}{$\begin{array}{l}\mathrm{I}_{\text {geo- }} \\
\text { class }\end{array}$} & \multicolumn{2}{|c|}{ Suspended } & \multicolumn{2}{|c|}{ particuiate } & \multicolumn{4}{|c|}{ Bottom sediment } \\
\hline & & $\mathrm{u}$ & M & L & $E$ & $\mathrm{u}$ & M & L & $E$ \\
\hline $2-3$ & 3 & $\mathrm{Cd}$ & $\mathrm{CdPb}$ & $\mathrm{CdPb}$ & $\mathrm{Cd}$ & & $c d$ & $\mathrm{Cd}$ & $\mathrm{CdPb}$ \\
\hline $1-2$ & 2 & $\underset{Z_{11}}{\text { Cupb }}$ & cuzs & $\mathrm{Zn}$ & $\operatorname{cdz} \pi$ & $\mathrm{cdPb}$ & $\mathrm{Pb}$ & $\mathrm{Pb}$ & $\mathrm{CdPb}$ \\
\hline $0-1$ & 1 & $\mathrm{Mn}$ & Mn & CuMn & cumn & $2 n$ & $2 n$ & $\mathrm{Zn}$ & $2 n$ \\
\hline$<0$ & 0 & $\mathrm{Fe}$ & F'e & $\mathrm{Fe}$ & FeMn & $\begin{array}{c}\text { FeMn } \\
\mathrm{Cu}\end{array}$ & $\begin{array}{c}\text { FeMn } \\
\mathrm{Cu}\end{array}$ & $\begin{array}{c}\text { FeMn } \\
\mathrm{Cu}\end{array}$ & $\begin{array}{l}\text { FeMn } \\
\text { CuZn }\end{array}$ \\
\hline
\end{tabular}

U: Upper river; M: Middle river; L: Lower river; E: Estuary, covering a range of sampling stations.

always higher than those in the bottom sediments.

In order to know the degree of metal accumulation in particulates and sediments with respect to the background levels, we applied an "index of geoaccumulation (Igeo)", which was proposed by Muller (1979), to estimate metal accumulation in river basins. According to the Muller's equation,

$$
I g e o=\log _{2} C n / 1.5 B n,
$$

in which $C n$ is the measured concentration of the element " $n$ " in the pelitic sediment fraction $(<2 \mu \mathrm{m})$ and $B n$ is the geochemical background value in the fossilized argillaceous sediment (average shale); the factor 1.5 is used because of possible variations of the background data due to lithogenic effects. The results of estimated indices for metals in sediments and particulates from the Tsengwen river basin are shown in Table 3. It is evident that $C d$ and $P b$ were relatively enriched either in sediments or in particulates, while $Z n$ showed one class order behind the $C d$ and $P b$, whereas $F e$ and most of $M n$ and $C u$ showed no enrichment with respect to the background values. Spatial variations of metal pollution in the river basin can be revealed from the values of Igeo at different river locations as shown in Table 3. Because Igeo is free of the lithogenic effect, It can clearly reflect the effects of post-industry on metal accumulation. Consequently, the enriched sequence $(\mathrm{Cd}, \mathrm{Pb}>\mathrm{Zn}, \mathrm{Cu}>\mathrm{Fe}$, $\mathrm{Mn}$ ) corresponds somewhat to the accumulation of metals in fossil residue (Salomons and Forstner, 1984) which may act as a mirror for the cultural effects. 
Table 4 represents the metal contents in the particulates of the Tsengwen river, mean metal contents in the particulates of world rivers, metal contents of soils in the river basin, and typical metal contents of world soils. We found that particulate $F e, M n, C d$ and $C u$ in the Tsengwen river fall in the ranges close to the mean values of those in the world rivers; particulate $P b$ and $Z n$, however, are much lower than those in the world rivers. Nevertheless, particulate metals are much higher than those in the respective soils of the drainage basin. Obviously, riverine particulate metals were enriched with respect to the soil metals in the drainage basin. According to the viewpoints of Martin and Meybeck (1979), in the tropical areas the suspended matter of rivers mainly originates from weathered soil materials rather than from rock debris, and in this type of river the contents of particulate $\mathrm{Al}, \mathrm{Fe}$ and $\mathrm{Ti}$ are usually the highest, while the contents of particulate $\mathrm{Ca}$ and $\mathrm{Na}$ are the lowest. In our study the content ratios of metals between riverine particulate and drainage soils are 1.69 for $\mathrm{Fe}$, 3.55 for $M n, 9.57$ for $C d, 3.99$ for $C u, 6.39$ for $P b$, and 3.86 for $Z n$. This indicates an anthropogenic impact on the metal runoff pathways from drainage basin to the river.

Table 4. Comparison of metal concentration between suspended particulates in the river and soils of the basin.

\begin{tabular}{lcccc}
\hline Metai & $\begin{array}{c}\text { Particuiates } \\
\text { of } \\
\text { Tsengwen river } \\
\text { (range, ppm) }\end{array}$ & $\begin{array}{c}\text { Soils } \\
\text { of } \\
\text { Tsengwen basin } \\
\text { (range, ppm) }\end{array}$ & $\begin{array}{c}\text { Particulates } \\
\text { of } \\
\text { world rivers } \\
\text { (average,ppm) }\end{array}$ & world soils \\
\hline $\mathrm{Fe}$ & $3.37-4.228$ & $2.02-2.478$ & $4.8 \%$ & 3.28 \\
$\mathrm{Mn}$ & $1245-1318$ & $340-382$ & 1050 & 760 \\
$\mathrm{Cd}$ & $0.70-1.79$ & $0.071-0.13$ & $(1)$ & 0.6 \\
$\mathrm{Cu}$ & $52.1-81.9$ & $15.0-18.6$ & 100 & 26 \\
$\mathrm{~Pb}$ & $6 \% .3-70.5$ & $9.82-11.7$ & 150 & 29 \\
$\mathrm{Zn}$ & $224-293$ & $62-72$ & 350 & 60 \\
\hline
\end{tabular}

+ Martin and Meybeck (1979)

\# Ure and Berrow (i982)

In considering the fact that the metals transported by suspended matter may exist in different chemical forms with various strength for biota availability, particulate metal speciation through the transport en route was investigated. Fig. 5 displays the metal species distributions from the sampling stations on the Tsengwen river. Overall, the particulate metal speciation is rather dependent 

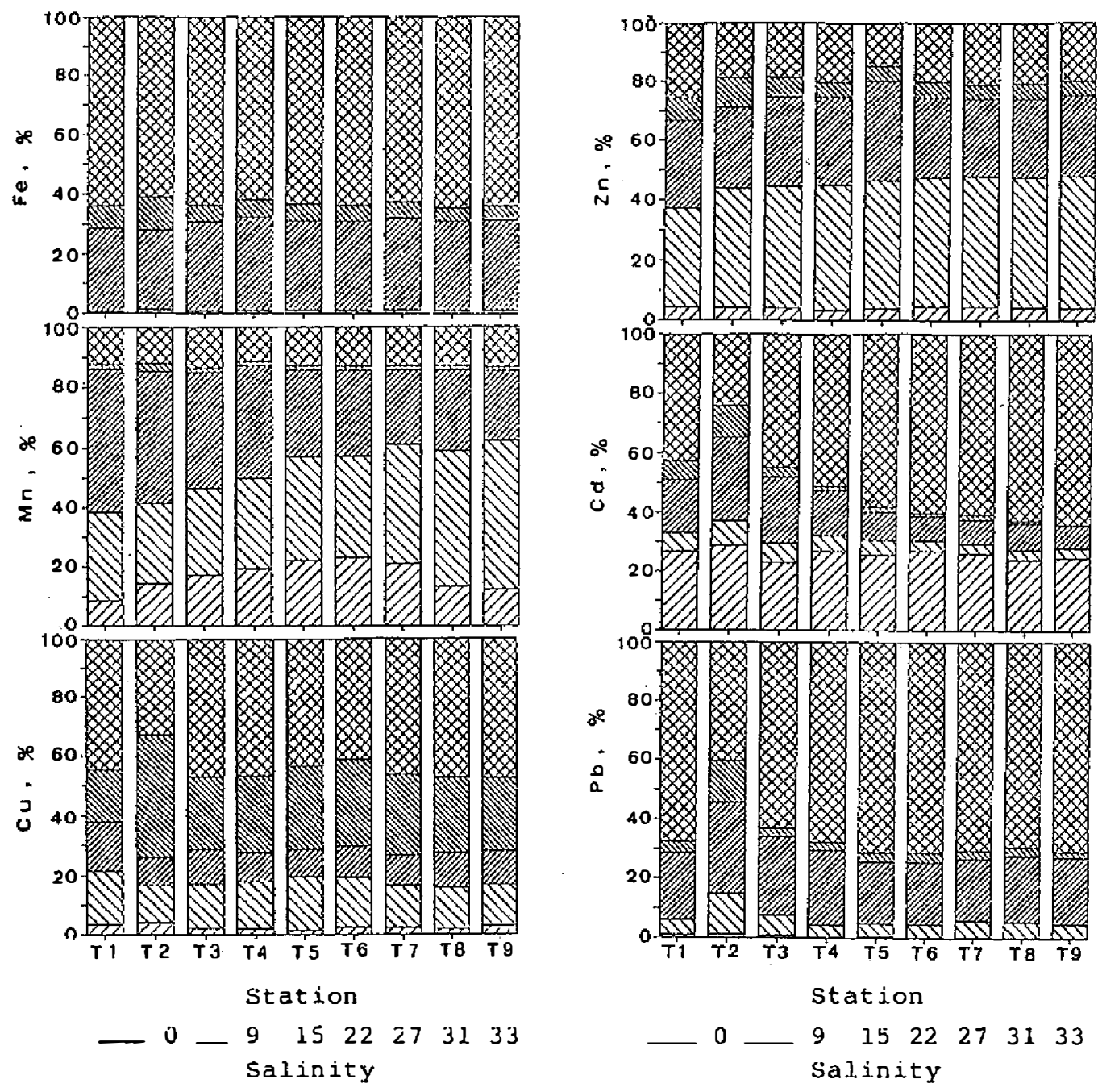

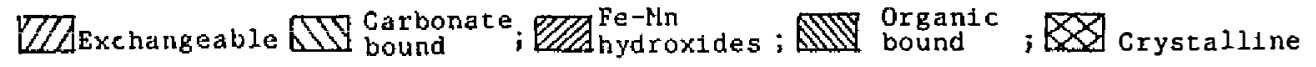

Fig. 5. Distribution of metal species in suspended particulates for the Tsengwen river and estuary.

on the metal type. Particulate $\mathrm{Fe}$ and $\mathrm{Pb}$ are mostly concentrated in the $\mathrm{Fe}$ $M n$ hydroxides and crystalline fractions. Particulate $M n, C u, Z n$ and $C d$ distribute rather significantly, in addition to $F e-M n$ hydroxides and crystalline fractions, in exchangeable and carbonate phases, carbonate and organic phases, the carbonate phase and exchangeable phase, respectively. The particulate metal speciation is little different between riverw ter and estuarine water. In general, metals in exchangeable, carbonate, $F e-M n$ hydroxides and organic phases are of both natural and anthropogenic origins; they are considered as 
potentially available, while metals incorporated in the structures of crystalline materials are essentially of geological origin and are usually inert toward the biota (Calmano and Forstner, 1983; Gibbs, 1977, Tessier et al., 1979).

Particulate metal species may be subject to alteration as suspended matter enters the estuary. Exchangeable metals may be released into the water if salt concentrations and organic complexing agents increase and $\mathrm{pH}$ decrease. Metals in $\mathrm{Fe}-\mathrm{Mn}$ hydroxides may be released if estuarine water becomes acidic or reduced. Organically-bound metals may become available to the biota through the decay of organic matter. Among the environmental factors examined in this system, $\mathrm{pH}$ and redox potential would contribute little to the alteration of metal speciation, because there is no significant change of $\mathrm{pH}(7.6-8.2)$ and dissolved oxygen content (4.6-6.5 $\mathrm{mg} \mathrm{L}^{-1}$ ) in the river system. Consequently, the increase of ionic strength (salt concentration), decay of organic matter, and increase of ligand concentration should be responsible for the shift in speciation.

Table 5. Riverine fluxes of metals from the Tsengwen river.

\begin{tabular}{cccc}
\hline Metals & Dissolved & \multicolumn{1}{c}{$\begin{array}{l}\text { Suspended } \\
\text { particulate }\end{array}$} & Total \\
\hline Fe & $33.6(0.06)^{*}$ & $60.346(99.94)^{8}$ & 60.380 \\
Mn & $13.2(0.71)$ & $1.854(99.29)$ & 1.867 \\
$\mathrm{Cd}$ & $0.07(6.60)$ & $0.99(93.40)$ & 1.06 \\
$\mathrm{Cu}$ & $3.72(4.76)$ & $74.5(95.24)$ & 78.2 \\
$\mathrm{~Pb}$ & $1.20(1.18)$ & $101(98.82)$ & 102 \\
$\mathrm{Zn}$ & $23.1(5.49)$ & $398(94.51)$ & 421 \\
\hline
\end{tabular}

* Dissolved load (ton/yr) = (Concentration of dissolved metal) $x$ (Annual discharge) \#

** Suspended load (ton/yr) $=$ (Concentration of suspended metal) $x$ (Annual load of suspended particulate) ${ }^{+}$

\# Annual discharge: $1.40 \times i 0^{9} \mathrm{~m}^{3} / \mathrm{yr}$ (Ave., 1972-1981)

+ Annual suspended load: $1.43 \times 10^{6}$ ton/yr (Ave.. 1972-1981)

e values in parentheses are the percentages of total concentrations

The annual discharge (gross fluxes) of metals from the Tsengwen river were estimated. They were calculated as the sum of dissolved and particulate metals averaged from high and low flows. From Table 5 we found that over $93 \%$ of the total fluxed metals were transported by the particulate phase. Gibbs (1977) 
has claimed that suspended sediments transport over $97 \%$ of the total mass of transition metals to the world's oceans. Martin and Meybeck (1979) have also found that the dissolved transport index in rivers only accounted for 0.1-10 $\%$ of most transition and rare earth elements in the world's rivers. Yeats and Bewers (1982), however, have estimated dissolved fluxes in less than $10 \%$ for $\mathrm{Al}, \mathrm{Fe}, \mathrm{Cu}$ and $\mathrm{Cd}$, but up to $28 \%$ for $M n, 48 \%$ for Co, $66 \%$ for $Z n$, and $74 \%$ for $\mathrm{Ni}$, in the St. Lawrence river in Canada. The difference was ascribed to the lower content of suspended matter and relative lack of pollution in the St. Lawrence river. The Tsengwen river discharged total metals approximately 0.004-0.01\% of those from other global rivers, but it discharged only $0.004 \%$ of the global amount in water discharge. Apparently trace metals transported by suspended matter are relatively important, and this could be relevant to the rapid denudation and erosion of rocks and soils in Taiwan.

\section{d. Mass-balance in the estuary}

An estuary can. be a sink or a source for river borne materials. In order to understand the net fluxes of metals into the coast, we shall use a box model (Fig. 6) to decribe the mass-balance of metals in the Tsengwen estuary. The boundary between the river and theestuary is the Kuosheng bridge, and the boundary between the estuary and the Taiwan Strait is the river mouth. Water flowing in and out the estuary is defined as $Q_{R}$, from the river, and $Q_{E}$, from the estuary, $Q_{O}$, is bottom water exchange from the Taiwan Strait.

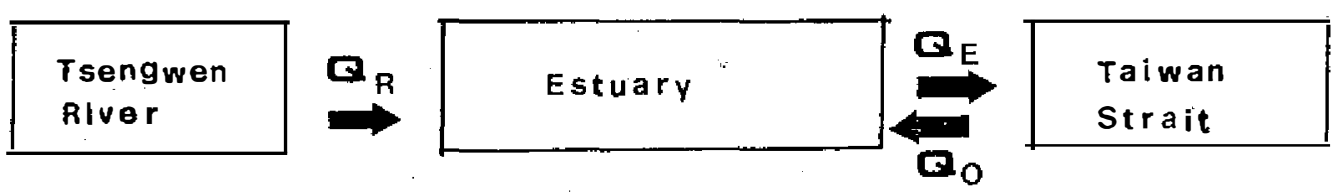

Fig. 6. A box model of metal transport in the Tsengwen estuary.

Because salinity is generally thought of as a conservative parameter (Klinkhammer and Bender, 1981), we apply the requirement of salt balance (equation 1) to derive a mass-balance condition. We calculated the mean salinity in the estuary $\left(S_{E}\right)$ from the salinity profile in Fig. $2\left(S_{E}=\sum S i \times V i / \sum V i\right.$, where $S i$ is one of the salinity values in Fig. 2 and $V i$ is the water volume of that salinity) and use sea-end salinity as the mean salinity in the box of the Taiwan Strait.

$$
\begin{gathered}
Q_{E} S_{E}=Q_{O} S_{O} \\
Q_{E}=Q_{O} S_{O} / S_{E} \\
Q_{E}=Q_{R}+Q_{O}
\end{gathered}
$$


Combining equations 2 and 3 , we obtain

$$
Q_{O}=\frac{Q_{R}}{\left(S_{O} / S_{E}-1\right)}
$$

Table 6. Chemical balance of metals in the Tsengwen estuary.

\begin{tabular}{cccccc}
\hline \multirow{2}{*}{ Element } & \multicolumn{2}{c}{ Influx (ton/Yr) } & & \multicolumn{2}{c}{ Outflux (ton/yr) } \\
\cline { 2 - 3 } \cline { 6 - 6 } & Dissolved & Particulate & & Dissolved & Particulate \\
\hline $\mathrm{Fe}$ & 40.7 & 60.432 & & $22.6(568) \star$ & $20.966(358)^{*}$ \\
$\mathrm{Mn}$ & 14.5 & 1.856 & & $11.0(768)$ & $598(328)$ \\
$\mathrm{Cd}$ & 0.11 & 0.99 & & $0.126(1148)$ & $0.28(288)$ \\
$\mathrm{Cu}$ & 4.70 & 74.6 & & $3.13(678)$ & $22.0(298)$ \\
$\mathrm{Pb}$ & 1.49 & 101 & & $1.25(848)$ & $38.9(398)$ \\
$\mathrm{Zn}$ & 29.4 & 399 & & $21.4(738)$ & $199(508)$
\end{tabular}

* Values in parentheses are percentages of outflux:influx.

The $S_{O}$ is taken as $34.50 / 00$ and $S_{E}$ is calculated to be $15.50 / 00$. The $Q_{R}$ is $1.40 \times 10^{9} \mathrm{~m}^{3} \mathrm{yr}^{-1}$. The $Q_{O}$ is then calculated to be $1.14 \times 10^{9} \mathrm{~m}^{3} \mathrm{yr}^{-1}$. Therefore, we can use the data listed in Figs. 3 and 4 and Table 5 to estimate the metal fluxes into and out of the Tsengwen estuary. From Table 6, we can see that about $56 \%, 76 \%, 114 \%, 67 \%, 84 \%$ and $73 \%$ of dissolved influxes as well as $35 \%, 32 \%, 28 \%, 29 \%, 39 \%$ and $50 \%$ of particulate influxes, respectively for $F e, M n, C d, C u, P b$ and $Z n$, are transported across the Tsengwen estuary. It seems that little of the particulate metals has been converted into the dissolved phase. Appartently, the imbalance of metals between the dissolved and particulate phases could be attributed to the deposition of metals in the estuary.

\section{CONCLUSION}

This comprehensive study provides data for understanding the transport mechanisms and hehaviors of trace metals in the Tsengwen river and its estuary. The data-shows that the Tsengwen riverwater has been slightly contaminated with anthropogenic metals in the middle and down streams. The riverborne dissolved metals with the exception of $C d$ behaved non- conservatively in the estuary. Dissolved $\mathrm{Fe}, \mathrm{Mn}, \mathrm{Cu}, \mathrm{Pb}$ and $\mathrm{Zn}$ exhibited significant removals in 
the initial mixing zone; $C d$, however, did not display a signal of removal or addition over the estuary. Concentrations of particulate and sediment metals, similar to those of dissolved metals, were higher in the middle river than in the adjacent stations, but there was little difference over the estuarine locations. The accumulated particulate and sediment metals with reference to baselines follow a sequence of $\mathrm{Pb}, \mathrm{Cd}>\mathrm{Zn}, \mathrm{Cu}>\mathrm{Fe}, \mathrm{Mn}$.

We also found that trace metals were mainly transported by suspended particulates, accounting for over $93 \%$ of total gross fluxes. The human impacts on this metal transport are clear. Particulate metal speciation is characteristic of metal geochemical properties and it is closely related to metal bioavailability. The net fluxes of metals out of the estuary are modeled as approximately $56 \%$, $76 \%, 114 \%, 67 \%, 84 \%$ and $73 \%$ of the dissolved influxes as well as $35 \%, 32$ $\%, 28 \%, 29 \%, 39 \%$ and $50 \%$ of the particulate influxes, respectively for $\mathrm{Fe}$, $M n, C d, C u, P b$ and $Z n$. The imbalance of metals between the dissolved and particulate phases is thought to result from metal deposition in the estuary. The net fluxes of metals may provide important clues for evaluating the effects of terrestrial sources on the quality and productivity of coastal water.

Acknowledgements. Thanks to Mr. C. C. Huang and Mrs. C. G. Tseng for their assistance with field work and laboratory analyses. Financial support for this study was given by the National Science Council of the Republic of China (NSC 76,77-0209-M110-01), and is gratefully acknowledged.

\section{REFERENCES}

Byrd, J. T. and M. O. Andreae, 1986: Geochemistry of tin in rivers and estuaries. Geochim. Cosmochim. Acta, 50, 835-845.

Calmano, W. and U. Forstner, 1983: Chemical extraction of heavy metals in polluted river sediments in central Europe. Sci. Total Environ., 28, 77-90.

Danielsson, L., B. Magnusson, B. Westerlund, and K. Zhang, 1982: Trace metal determinations in estuarine waters by electrothermal atomic absorption spectrometry after extraction of dithiocarbamate complexes into freon. Anal. Chim. Acta, 144, 183-188.

Eaton, A., 1979: Observations on the geochemistry of soluble copper, iron, nickel and zinc in the San Francisco Bay estuary. Environ. Sci. Technol., 13, 425-432.

Forstner, U. and G. Wittmann, 1979: Metal pollution in the aquatic environment, Springer, New York, 486 pp.

Galloway, J. N., 1979: Alteration of trace metal geochemical cycles due to marine discharge of wastewater. Geochim. Cosmochim. Acta, 43, 207: 218. 
Gibbs, R. J., 1973: Mechanisms of trace metal transport in rivers. Science, 180, 71-73.

Gibbs, R. J., 1977: Transport phases of transition metals in the Amazon and Yukon rivers. Geol. Soc. Am. Bullet., 88, 829-843.

Hung, J. J., 1988: Determination of trace metal species in the suspended matter of riverine and estuarine waters. J. Chin. Chem. Soc., 35, 119-124.

Hung, J. J. and C. C. Huang, 1990: Geochemical distribution and transport of trace metals in the Kaoping riverine, estuarine and coastal waters, Proc. Natl. Sci. Counc., R.O.C., (in press).

Keeney-Kennicutt, W. and B. J. Presley, 1986: The geochemistry of trace metals in the Brazos River Estuary. Estuar. Coast. Shelf Sci., 22, 459-477.

Klinkhammer, G. P. and M. L. Bender, 1981: Trace metal distributions in the Hudson River Estuary. Estuar. Coast. Shelf Sci., 12, 629-643.

Li, Y. H., L. Burkhardt, and H. Teraoka, 1984: Desorption and coagulation of trace elements during estuarine mixing. Geochim. Cosmochim. Acta, 48, 1879-1884.

Loring, D. H., 1978: Geochemistry of zinc, copper and lead in the sediments of the estuary and Gulf of St. Lawrence. Can. J. Earth Sci., 15, 757-772.

Maest, A. S., 1984: The geochemistry of metal transport in low and high temperature aqueous systems, $\mathrm{Ph}$. D. thesis, Princeton Univ., N. J.

Martin, J-M and M. Meybeck, 1979: Elemental mass-balance of material carried by major world rivers. Mar. Chem., 7, 173-206.

Muller, G., 1979: Schwermetalle in den sedimenten der Elbe bei Stade. Naturwiss, 67, 560 .

Osipow, L. I., 1977: Surface chemistry: Theory and industrial applications, Robert E. Krieger Pub., New York, p.135.

Salomons, W. and W. G. Mook, 1977: Trace metal concentrations in estuarine sediments: mobilization, mixing or precipitation. Neth. J. Sea Res., 11, 119-129.

Salomons, W. and U. Forstner, 1984: Metals in the hydrocycle, Springer-Verlag, New York, $349 \mathrm{pp}$.

Sholkovitz, E. R., 1978: The flocculation of dissolved $F e, M n, A l, C u, N i$, Co and Cd during estuarine mixing. Earth Planet. Sci. Letts, 41, 77-86.

Stallard, R. F. and J. M. Edmond, 1983: Geochemistry of the Amazon: 2. The influence of geology and weathering environment on the dissolved load. $J$. Geophy. Res., 88, 9671-9688.

Statham, P. J., 1985: The determination of dissolved manganese and cadmium in seawater at low $\mathrm{nmol} / \mathrm{L}$ concentrations by chelation and extraction followed by electrothermal atomic absorption spectrometry. Anal. Chim. Acta, 169, 149-159.

Tessier, A., P. G. C. Campbell and M. Bisson, 1979: Sequential extraction 
procedure for the speciation of particulate trace metals. Anal. Chem., 51, 844-851.

Trefry, J. H. and B. J. Presley, 1976: Heavy metal transport from the Mississippi River to the Gulf of Mexico. In: H. L. Windom and R. A. Duce (eds.). Marine pollution transfer, Lexington Books, Lexington, MA, p.391.

Ure, A. M. and M. L. Berrow, 1982: The chemical constituents of soils. In: H. J. M. Bowen (ed.). Environmental Chemistry, R. Soc. Chem., Burlington House, London, 2, 94-202.

Waslenchuck, D. G. and H. L. Windom, 1987: Factors controlling the estuarine chemistry of arsenic. Estuar. Coast Mar. Sci., 71, 455-464.

Windom, H. L., R. Dulamge, and F. Storti, 1983: Behavior of copper in southeastern United States estuaries. Mar. Chem., 12, 183-193.

Yeats, P. A. and J. M. Bewers, 1982: Discharge of metals from the St. Lawrence River. Can. J. Earth Sci., 19, 983-992. 


\title{
曾文河川及河口地區微量金屬 之輸送及行為研究
}

\author{
洪佳草 \\ 國立中山大學海洋地質研究所
}

摘要

本研究係探討鐵、鎾、鎘、銅、鉛、鋅等微量元素在曾文河川及河口地區之地化行爵與 輸送機制。曾文溪河川溶解態金屬, 均在中游或下游有較高的分佈。一般而监, 微量金屬濃 度均比世界河川背景檤稍高, 但比活染嚴重之河川爲低。溶解態鐵、錳、鉰、鉛、鋅在河口 地區均有移除現象發生, 而鎘䐣未有顯移除或添加現象。眸浮顆粒與沉積物金屬在河川中游 亦有較高的濃度, 但在河口各站中均未有明顯的分佈差異。由地化累積指數可以看出䀥浮顆 粒與沉積物金屬之富集程度依序爲Pb、Cd>Cu、 $\mathrm{Zn}>\mathrm{Fe} 、 \mathrm{Mn}$ 。

曾文河川中微量金屬元素主要經由㷂浮顆粒之輸㑒，約佔總輸迼量之93\%以上，且在輸 途過程中已受到人爲污染之影響。顆粒性微量金屬元素之物種分作取決於元素種類。鐵及鉛 主要存在於鐵鍴氧化物及磺物晶體中。錳、銅、鋅、鎘則除了行佈於鐵錳氧化物及磺物晶體

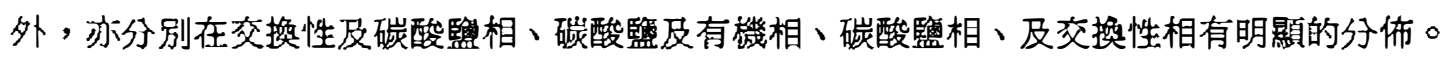
利用箱型模式估算結果發現，對輸入河口的鐵、錳、鎘、銅、鉛、鋅而言，行別有56\%，76 $\%, 114 \%, 67 \%, 84 \%$ 及 $73 \%$ 的溶解態以及35\%,32\%，28\%，29\%，39\%，及50\%之顆 粒態通過河口進入台灣海峽。因此河口中溶解相與顆粒相中金蜴元素之質量差異部份相信已 沈積於河口之沈積物中。 
